OPEN ACCESS

Edited by:

P. Bryant Chase,

Florida State University, United States

Reviewed by:

Takahiko Shimizu,

Chiba University, Japan

Robert W. Wiseman

Michigan State University,

United States

*Correspondence:

Malte Stockebrand

malte.stockebrand@dzne.de

†These authors have contributed equally to this work.

Specialty section: This article was submitted to

Striated Muscle Physiology, a section of the journal

Frontiers in Physiology

Received: 26 March 2018

Accepted: 04 June 2018

Published: 22 June 2018

Citation:

Stockebrand M, Sasani A, Das D, Hornig S, Hermans-Borgmeyer I,

Lake HA, Isbrandt D, Lygate $C A$, Heerschap A, Neu A and Choe C-U (2018) A Mouse Model of Creatine

Transporter Deficiency Reveals Impaired Motor Function and Muscle Energy Metabolism.

Front. Physiol. 9:773.

doi: 10.3389/fphys.2018.00773

\section{A Mouse Model of Creatine Transporter Deficiency Reveals Impaired Motor Function and Muscle Energy Metabolism}

\author{
Malte Stockebrand ${ }^{1,2 * t}$, Ali Sasani3,4t, Devashish Das ${ }^{5 \dagger}$, Sönke Hornig ${ }^{4}$, \\ Irm Hermans-Borgmeyer6, Hannah A. Lake ${ }^{7,8}$, Dirk Isbrandt'1, Craig A. Lygate7,8, \\ Arend Heerschap ${ }^{5}$, Axel $\mathrm{Neu}^{4+}$ and Chi-Un Choe ${ }^{3+}$
}

\begin{abstract}
' German Center for Neurodegenerative Diseases, Bonn, Germany, ${ }^{2}$ Institute for Molecular and Behavioral Neuroscience, University of Cologne, Cologne, Germany, ${ }^{3}$ Department of Neurology, University Medical Center Hamburg-Eppendorf, Hamburg, Germany, ${ }^{4}$ Experimental Neuropediatrics, Department of Pediatrics, University Medical Center Hamburg-Eppendorf, Hamburg, Germany, ${ }^{5}$ Department of Radiology, Radboud University Nijmegen Medical Center, Nijmegen, Netherlands, ${ }^{6}$ Transgenic Mouse Unit, Center for Molecular Neurobiology Hamburg, University Medical Center Hamburg-Eppendorf, Hamburg, Germany, ${ }^{7}$ Division of Cardiovascular Medicine, Radcliffe Department of Medicine, BHF Centre of Research Excellence, University of Oxford, Oxford, United Kingdom, ${ }^{8}$ Wellcome Centre for Human Genetics, University of Oxford, Oxford, United Kingdom
\end{abstract}

Creatine serves as fast energy buffer in organs of high-energy demand such as brain and skeletal muscle. L-Arginine:glycine amidinotransferase (AGAT) and guanidinoacetate $N$-methyltransferase are responsible for endogenous creatine synthesis. Subsequent uptake into target organs like skeletal muscle, heart and brain is mediated by the creatine transporter (CT1, SLC6A8). Creatine deficiency syndromes are caused by defects of endogenous creatine synthesis or transport and are mainly characterized by intellectual disability, behavioral abnormalities, poorly developed muscle mass, and in some cases also muscle weakness. CT1-deficiency is estimated to be among the most common causes of X-linked intellectual disability and therefore the brain phenotype was the main focus of recent research. Unfortunately, very limited data concerning muscle creatine levels and functions are available from patients with CT1 deficiency. Furthermore, different CT1-deficient mouse models yielded conflicting results and detailed analyses of their muscular phenotype are lacking. Here, we report the generation of a novel CT1-deficient mouse model and characterized the effects of creatine depletion in skeletal muscle. HPLC-analysis showed strongly reduced total creatine levels in skeletal muscle and heart. MR-spectroscopy revealed an almost complete absence of phosphocreatine in skeletal muscle. Increased AGAT expression in skeletal muscle was not sufficient to compensate for insufficient creatine transport. CT1-deficient mice displayed profound impairment of skeletal muscle function and morphology (i.e., reduced strength, reduced endurance, and muscle atrophy). Furthermore, severely altered energy homeostasis was evident on magnetic resonance spectroscopy. Strongly reduced phosphocreatine resulted in decreased ATP/Pi levels despite an increased inorganic phosphate to ATP flux. Concerning glucose metabolism, we show increased glucose transporter type 4 expression in muscle and improved 
glucose clearance in CT1-deficient mice. These metabolic changes were associated with activation of AMP-activated protein kinase - a central regulator of energy homeostasis. In summary, creatine transporter deficiency resulted in a severe muscle weakness and atrophy despite different compensatory mechanisms.

Keywords: creatine transporter, skeletal muscle, energy metabolism, in vivo magnetic spectroscopy, L-arginine:glycine amidinotransferase (AGAT), guanidinoacetate $\mathrm{N}$-methyltransferase (GAMT), glycine amidinotransferase (GATM), SIc6a8

\section{INTRODUCTION}

Energy supply for muscle contraction is provided by breakdown of adenosine triphosphate (ATP), which is replenished continuously by anaerobic glycolysis or oxidative phosphorylation. The (P)Cr system serves as rapid energy buffer to maintain constant ATP levels and mediates subcellular highenergy phosphate transfer. Therefore, high (P)Cr levels are found in skeletal muscle in concentrations up to $20-40 \mathrm{mM}$ (Wyss and Kaddurah-Daouk, 2000). As non-enzymatic degradation of creatine to creatinine takes place at a daily rate of $1.7 \%$ (Wyss and Kaddurah-Daouk, 2000), the Cr pool has to be replenished via dietary intake or endogenous Cr synthesis. AGAT (EC 2.1.4.1) and GAMT (EC 2.1.1.2) are responsible for $\mathrm{Cr}$ synthesis from arginine, glycine, and $S$-adenosyl-methionine, which mainly takes place in kidney and liver. Subsequent uptake of $\mathrm{Cr}$ into organs such as brain, heart, and muscle is mediated by the $\mathrm{Cr}$ transporter (CT1, SLC6A8).

Defects of $\mathrm{Cr}$ synthesis or transport due to mutations in AGAT, GAMT, or SLC6A8 (CT1) genes are associated with $\mathrm{Cr}$ deficiency syndromes that affect brain and muscle to various degrees (Stockler et al., 2007). Patients with CT1 deficiency are especially prone to intellectual disability, behavioral abnormalities and seizures. Mutations in SLC6A8 are relatively frequent and were found in up to $2 \%$ of cases of X-linked intellectual disability (van de Kamp et al., 2014). Slender habitus and poorly developed muscle mass are the most striking anthropometric features of CT1 deficiency. Motor dysfunction can affect CT1-deficient patients, with muscular hypotonia in $10 \%$ and, less common, unspecific myopathic symptoms (Mancini et al., 2005; Puusepp et al., 2010; van de Kamp et al., 2014, 2015). Significant amounts of Cr were still detectable in the skeletal muscle of examined patients and studied knockout mice. However, a significant reduction of muscle $\mathrm{Cr}$ was only visible in mouse models. The relatively preserved $\mathrm{Cr}$ levels in skeletal muscle of CT1-deficient patients may possibly be due to endogenous $\mathrm{Cr}$ synthesis, non-specific uptake or residual activity of patients' mutant CT1 (deGrauw et al., 2003; PyneGeithman et al., 2004; Russell et al., 2014; Baroncelli et al., 2016).

\footnotetext{
Abbreviations: AGAT, L-arginine:glycine amidinotransferase; AMPK, AMPactivated protein kinase; Cr, creatine; CSA, cross-sectional area; CT1, creatine transporter; GAMT, guanidinoacetate $N$-methyltransferase; GLUT4, glucose transporter 4; $k_{\mathrm{f}}$, (pseudo-first order unidirectional) forward rate constant (for $\mathrm{Pi} \rightarrow \mathrm{ATP}$ ); MRS, magnetic resonance spectroscopy; $\mathrm{PCr}$, phosphocreatine; (P)Cr, either phosphocreatine or creatine; $\mathrm{Pi}$, inorganic phosphate; PMEs, phosphomonoesters.
}

We previously generated and characterized mouse models with AGAT and GAMT deficiency (Schmidt et al., 2004; Choe et al., 2013b). In addition to pronounced CNS and metabolic phenotypes, these mice displayed impaired muscle strength and muscle atrophy underlining the role of the $(\mathrm{P}) \mathrm{Cr}$ system in skeletal muscle (Torremans et al., 2005; Nabuurs et al., 2013). Previous studies on CT1-deficient mouse models have focused on the central nervous system. The muscle phenotype has not yet been analyzed in detail and the preliminary characterization generated conflicting results from different models and methodological approaches (Skelton et al., 2011; Russell et al., 2014; Baroncelli et al., 2016). Therefore, we generated and characterized CT1-deficient mice with a focus on muscle physiology. Our novel CT1-deficient mouse model revealed $(\mathrm{P}) \mathrm{Cr}$ deficiency in skeletal muscle associated with impaired motor function and muscle atrophy, which is in agreement with previous models (Russell et al., 2014; Baroncelli et al., 2016). Magnetic resonance spectroscopy experiments were performed to elucidate the high-energy phosphate metabolism in skeletal muscle of CT1-deficient mice. Furthermore, glucose metabolism, enzymes of creatine biosynthesis, and proteins of oxidative phosphorylation were studied in skeletal muscle of CT1-deficient mice to elucidate altered pathways.

\section{MATERIALS AND METHODS}

\section{Ethics Statement}

All animal procedures were conducted in accordance with institutional and national guidelines and were approved by the respective local animal ethics committees (Hamburg: 11/89 and 12/86, Nijmegen: RU-DEC2012-184). All experimental procedures conformed with the Guide for the Care and Use of Laboratory Animals published by the US National Institutes of Health (NIH Publication No. 83-123, revised 1996) and were performed in accordance with the ARRIVE guidelines. Mice used in this study were obtained from heterozygous matings. CT1-deficient knockout $\left(\mathrm{CT} 1^{-/ y}\right)$ mice and controls were age- and sex-matched littermates. Mice $(<5$ per cage) were kept in standard cages under a $12-12 \mathrm{~h}$ lightdark cycle, constant temperature, and humidity, and received standard food and water ad libitum. Chow was essentially Cr free (R/M-H, Ssniff), as previously shown (Schmidt et al., 2004).

\section{Generation of CT1-Deficient Mice}

In brief, CT1-deficient knockout $\left(\mathrm{CT} 1^{-/ y}\right)$ mice were generated by injection of embryonic stem cells (ESCs) containing a targeted 
CT1 (Slc6a8) locus obtained from the NIH Knock-out Mouse Program (KOMP, project CSD24513, Slc6a $8^{\text {tmla(KOMP)Wtsi }}$ allele in ES cell clone EPD0293_6_E05). The ESCs from the parental line JM8A1.N3 (C57Bl/6N derived; Pettitt et al., 2009) had been targeted with a targeting-vector (PRPGS00081_A_A09) consisting of all 13 Slc6a exons with loxP sites flanking exons 5-8 (Skarnes et al., 2011). The targeted allele contains an insertion of a beta-galactosidase/lacZ reporter expression cassette (L1L2_Bact_P) with a splice acceptor site in the intron between exons 4 and 5, for the detection of Slc6a8 gene expression. The ESC clone was expanded and microinjected into $\mathrm{C} 57 \mathrm{BL} / 6 \mathrm{~J}$ mouse blastocysts, which were then transferred into pseudo-pregnant C57BL/6J females. Chimeric mice were mated and gave rise to germ-line transmission of the disrupted allele. Mice were backcrossed for several generations to C57BL/6J genetic background with negative selection for the $\mathrm{Rd} 8$ mutation in the F1 generation. Genomic DNA from mouse-tail or ear biopsies was screened by multiplex polymerase chain reaction (PCR) following standard protocols. Sequencing of genomic PCR-products between exons 7 and 8 revealed absence of the $3^{\prime}$ loxP site from the conditional Slc6a $8^{\text {tmla(KOMP)Wtsi }}$ allele. Therefore, according to the KOMP mutagenesis scheme, the correct description of the targeted, non-conditional allele is $\operatorname{Slc} 6 a 8^{\mathrm{tm} 1 \mathrm{e}(\mathrm{KOMP}) W \mathrm{tsi}}$ knock out first allele.

\section{cDNA Preparation and PCR}

Disruption of the murine CT1 gene was confirmed by touch down PCR of skeletal muscle cDNA using primers binding in exons 7 and 9 (Figure 1B). Total RNA of knock-down and wild-type mice was isolated using TRIzol reagent (Invitrogen) according to the manufacturer's instructions. DNase I treatment was performed to remove genomic DNA. One microgram of total RNA was used for random primed reverse transcription using the First Strand cDNA Synthesis Kit (Thermo Scientific) according to standard protocols. cDNAs were stored at $-20^{\circ} \mathrm{C}$. Exon spanning primers (forward: $5^{\prime}$-tcctggcactcatcaacag- $3^{\prime}$, reverse: $5^{\prime}$ atgaagccctccacacctac- $3^{\prime}$ ) were taken from Ireland et al. (2009) expecting a $250 \mathrm{bp}$ PCR product in wild-type reaction. Touch down PCR was performed using the following protocol: annealing temperature was decreased in 12 steps from $60^{\circ} \mathrm{C}$ by $0.5^{\circ} \mathrm{C}$ to $54^{\circ} \mathrm{C}$ followed by 25 cycles at $54^{\circ} \mathrm{C}$.

\section{Rotarod Test}

Mice had to walk on a turning, corrugated rod $(3.2 \mathrm{~cm}$ in diameter) (Acceler. Rotarod for mice, Jones \& Roberts, TSE 308 systems, Bad Homburg, Germany). The rod was started to rotate $5 \mathrm{~s}$ after the mice were placed onto it. Mice underwent five trials with an inter-trial-interval (ITI) of $45 \mathrm{~min}$, and performed at slow, constant speed [i.e., 4 rotations per minute (rpm)] for a maximum duration of $3 \mathrm{~min}$. Trials 3-5 were performed with the accelerating rod, starting with $4 \mathrm{rpm}$ up to $40 \mathrm{rpm}$ within $4 \mathrm{~min}$, with a maximum duration of $10 \mathrm{~min}$. On the following day, a sixth trial was carried out with the accelerating rod. The performance of the mice was evaluated by scoring the latency to fall. Experiments were performed blinded.

\section{Pole Test}

The animals were placed on top of a vertical $48.5 \mathrm{~cm}$-long rod made of rough wood with a diameter of $0.8 \mathrm{~cm}$. To motivate the mouse to climb down, nesting material of the home cage was placed at the bottom of the pole. The mouse was placed with its head facing upward and its four paws grasping the rod. The time required by the mouse to reach the floor (maximum duration of each trial was $80 \mathrm{~s}$ ) was recorded. Each mouse had to perform three consecutive trials with an ITI of $30 \mathrm{~s}$. The ability of a mouse to turn $180^{\circ}$ and climb down with the head pointing downward was evaluated. When the mouse turned, we recorded whether it turned at the top (level 1, above $32 \mathrm{~cm}$ ), at the middle (level 2, between 32 and $16 \mathrm{~cm}$ ), or at the bottom of the rod (level 3, below $16 \mathrm{~cm})$. Experiments were performed blinded.

\section{Grip Strength}

Maximal grip force was measured using a grip strength meter (TSE-Systems, Bad Homburg, Germany) as described previously (Nabuurs et al., 2013). Within each group, the mean grip force of each mouse was calculated from 15 appropriate trials. Experiments were performed blinded.

\section{Voluntary Running Wheel}

Mice were provided with a vertical, ridged running wheel (tierisch.de, Flensburg, Germany). The wheels were fixed in the cage using magnets. Wheel rotation was monitored using a magnetic read switch attached to a counter. Running distances were calculated based on the number of rotations within $24 \mathrm{~h}$ and the circumference of the running wheel $(41.41 \mathrm{~cm})$. Experiments were performed blinded.

\section{Muscle Histopathology}

Muscle histology was performed as previously described (Nabuurs et al., 2013). Briefly, mice were transcardially perfused with $4 \%$ formaldehyde in PBS. For morphometry, commonly stained slides for hematoxylin and eosin (H\&E) were used. Myocyte diameters and CSA were determined in multiple transverse sections of muscle using ImageJ and calculated by averaging the data of five images. Determination of myocyte diameters was performed blinded.

\section{In Vivo ${ }^{1} \mathrm{H}$ MRI and ${ }^{31} \mathrm{P}$ MRS}

Male $\mathrm{CT} 1^{+/ y}$ and $\mathrm{CT} 1^{-/ y}$ mice, aged $120-180$ days, were placed in prone position in the magnet bore under anesthesia with $1-2 \%$ isoflurane in a $2: 1$ air $/ \mathrm{O}_{2}$ mixture and maintained at $37 \pm 1^{\circ} \mathrm{C}$ using warm air under control of a rectal sensor (Luxtron 712, Santa Clara, CA, United States). Breathing rate (50-70/min) was monitored by a respiratory pad attached to the chest. Measurements were performed on an 11.7T Biospec Avance III small animal MR system (Bruker, Biospin, Germany). The hind legs of mice were placed in a home-built $8 \mathrm{~mm}$ diameter radiofrequency (RF) probe consisting of $a^{1} \mathrm{H}$ and a ${ }^{31} \mathrm{P}$ coil. Gradient-echo localizer MR images were obtained in three orthogonal directions followed by localized magnetic field shimming. Then a $2 \mathrm{D}$ gradient-echo image was obtained of a $2 \mathrm{~mm}$ thick transversal slice, positioned at the largest 
CSA distal from the knee joint $(\mathrm{FOV}=2 \mathrm{~cm} \times 2 \mathrm{~cm}$, matrix size $=128 \times 128$, resolution $=0.156 \mathrm{~mm} \times 0.156 \mathrm{~mm}$, $\mathrm{TR}=100 \mathrm{~ms}, \mathrm{TE}=6 \mathrm{~ms})$. Non-localized ${ }^{31} \mathrm{P} \mathrm{MR}$ spectra of the leg (gastrocnemius/plantaris/soleus complex) were recorded using an excitation block pulse of $100 \mu$ s with a $45^{\circ}$ flip angle, a $8012 \mathrm{~Hz}$ sweep width, 4096 data points, $256 \mathrm{~ms}$ acquisition time, TR $5 \mathrm{~s}$, 128 averages for $\mathrm{CT} 1^{+/ y}$ and $400-512$ averages for $\mathrm{CT} 1^{-/ y}$ mice. ${ }^{31} \mathrm{P}$ saturation transfer (ST) MRS experiments were performed to derive the $\mathrm{Pi} \rightarrow \mathrm{ATP}$ (pseudo first order) forward rate constant $k_{\mathrm{f}}$ in the leg muscles (Nabuurs et al., 2010, 2013) using Gaussian frequency selective saturation pulses (1000 points, duration $100 \mathrm{~ms}$, selectivity $\sim 50 \mathrm{~Hz}$ ) with pulse power optimization for complete resonance saturation $(\sim 370 \mathrm{rad} / \mathrm{sec})$. Saturation was applied at the $\gamma$ ATP frequency and its mirror frequency around the $\mathrm{Pi}$ peak using looped incremental saturation periods of 0.1 , $0.2,0.4,0.6,1.0,1.5$, and $3 \mathrm{~s}$ (Koretsky et al., 1985; Nabuurs et al., 2010). Total TR was 5 s (2 s TR +3 s ST block) with $128\left(\mathrm{CT}^{+/ y}\right)$ or $512\left(\mathrm{CT}^{-/ \mathrm{y}}\right)$ averages.

From the single slice 2D-gradient echo MR images the muscle CSA of the lower hind leg (mostly gastrocnemius-plantarissoleus) of $\mathrm{CT} 1^{+/ \mathrm{y}}(n=5)$ and $\mathrm{CT} 1^{-/ \mathrm{y}}(n=4)$ was determined including a correction of the area occupied by bone $\left(2 \mathrm{~mm}^{2}\right)$. From this corrected CSA and the BATP peak integral the ATP tissue concentration in $\mathrm{CT} 1^{-/ y}$ mice was estimated assuming similar load of the RF coil by the hind legs of both mice and a tissue [ATP] of $7.8 \mathrm{mM}$ for $\mathrm{CT}^{+}{ }^{+} \mathrm{y}$ mice (in 't Zandt et al., 2003; Nabuurs et al., 2013). The assessment of the integrals of peaks and tissue $\mathrm{pH}$ from the $\mathrm{PCr}-\mathrm{Pi}$ chemical shift in the ${ }^{31} \mathrm{P}$ MR spectra were done as described before (Nabuurs et al., 2010, 2013). From the PCr/ATP and $P_{i} / A T P$ signal ratios we estimated tissue levels of $\mathrm{PCr}$ and $\mathrm{P}_{\mathrm{i}}$ after correction for T1 saturation. For $\mathrm{P}_{\mathrm{i}}$ a $\mathrm{T} 1$ of $1.95 \mathrm{~s}$ was applied (Nabuurs et al., 2010; Tyler et al., 2010). T1 values, for PCr and $\beta$ ATP, derived from skeletal muscle of $3 \mathrm{CT}^{+/ \mathrm{y}}$ mice at $11.7 \mathrm{~T}$ using inversion recovery, were $2.25 \pm 0.118$ and $0.656 \pm 0.07 \mathrm{~s}$, respectively. The muscle $\mathrm{Pi} \rightarrow$ ATP flux was obtained as the $k_{\mathrm{f}} \mathrm{x}\left[\mathrm{P}_{\mathrm{i}}\right]$ product (Nabuurs et al., 2013).

\section{Determination of Total Creatine}

Total Cr levels were measured by HPLC from homogenized samples with normalization to non-collagen protein, adapted from Teerlink et al. (1993), as described previously (Zervou et al., 2016).

\section{Glucose Tolerance Tests}

Mice were fasted for 14-16 h and intraperitoneally injected with glucose (2 g per kg body weight). Blood glucose was measured from tail capillary blood and collected at indicated times, as previously described (Choe et al., 2013b). Experiments were performed blinded.

\section{Tissue Collection and Preparation}

Animals were anesthetized with an intraperitoneal injection of ketamine and xylazine or by $2-3 \%$ isoflurane in $100 \%$ oxygen. Muscles were removed and flash frozen in liquid nitrogen. Lysates were prepared in homogenization buffer containing phosphatase inhibitors with disposable $1.5-\mathrm{mL}$ pestles (VWR) and cleared by centrifugation (Choe et al., 2013b). Protein concentrations were determined using a $\mathrm{BCA}^{\mathrm{TM}}$ protein assay (Thermo Scientific).

\section{Western Blots}

Equal amounts of cleared lysates (20-40 $\mu \mathrm{g}$ protein) were separated by SDS-PAGE on precast gels (Invitrogen) and transferred to nitrocellulose membrane. Antibodies against AGAT (Santa Cruz), GAMT (Eurogentec), GLUT4 (Acris Antibodies), Actin (Sigma Aldrich), UCP3 (Abcam), COX4 (Life technologies), pAMPK, pACC, and AMPK (all Cell Signaling) were used according to the manufacturers' protocols. Enhanced chemiluminescence (Luminata Crescendo, Millipore) signals were detected with a luminescent image analyzer (LAS-4000, FujiFilm). Total protein was measured with a laser scanner (FLA9000 with LPG filter, FujiFilm) on blot membranes stained with Lava Purple (Fluorotechnics, Gel Company) according to the manufacturer's instructions. Signal quantification was performed on non-saturated images using ImageJ software.

\section{Statistical Analysis}

Data are given as mean \pm SEM. The following statistical tests were applied: parametric $t$-test, one-way ANOVA or two-way ANOVA followed by Newman-Keuls post hoc comparisons (GraphPad Prism). All tests were two-tailed and the level of significance was set at $P<0.05$.

\section{RESULTS}

\section{Reduced Creatine Levels in Skeletal Muscle of CT1-Deficient Mice}

Targeted disruption of the Slc6a8 gene in ESCs was employed to prevent functional expression of CT1 protein (Figure 1A). $C T 1^{-/ y}$ mice were born at the expected Mendelian ratio, were viable and did not require any specific treatment for survival or growth. In cDNA prepared from total RNA of skeletal muscle no expression of the CT1 gene could be detected in $C T 1^{-/ y}$ mice with gene specific PCR whereas a PCR product was observed in $C T 1^{+/ y}$ mice (Figure 1B). HPLC-analysis revealed a 10 -fold reduction of $\mathrm{Cr}$ levels in heart and skeletal muscle, i.e., extensor digitorum longus and soleus muscle (Table 1). Cerebral Cr levels were also reduced, but only by about $70 \%$ (Table 1). No difference of $\mathrm{Cr}$ levels was observed in kidney, which is the main organ of endogenous $\mathrm{Cr}$ biosynthesis (Table 1). Expression of LacZ revealed widespread activity of $C T 1$ promoter in skeletal muscle (Figures 1C,D). Thus, we successfully generated a CT1-deficient mouse line for muscle phenotype analysis.

\section{Cr Biosynthesis in Skeletal Muscle of CT1-Deficient Mice}

In rodents, only very low AGAT and GAMT activities were found in skeletal muscle (Van Pilsum and Warhol, 1963; Daly, 1985). However, Cr deficiency has been shown to alter AGAT protein expression. For example, GAMT-deficient mice display compensatory upregulation of AGAT expression in kidney (Choe et al., 2013a). Furthermore, AGAT expression in skeletal muscle 


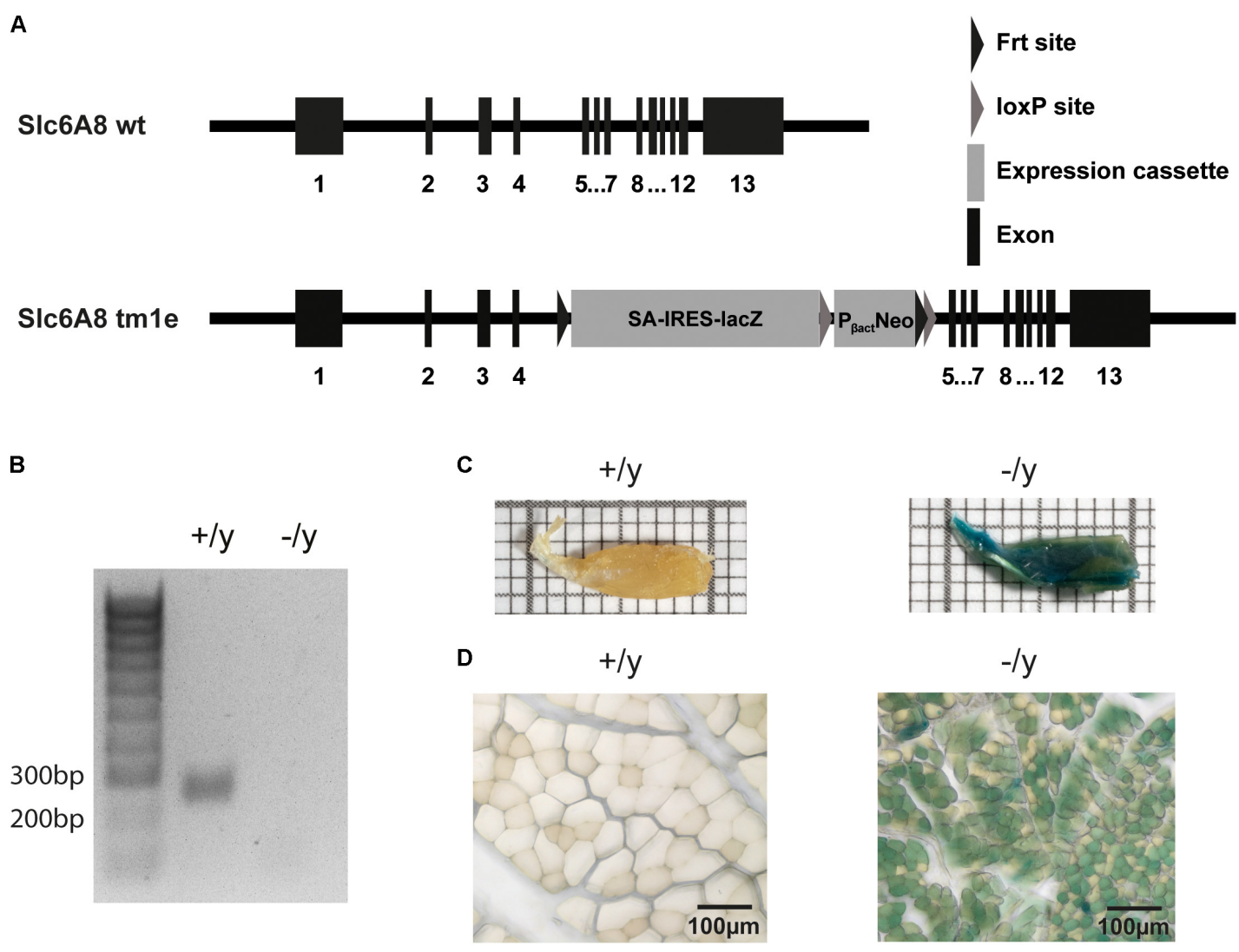

FIGURE 1 | Generation and characterization of CT1-deficient mice. (A) The CT1 gene was disrupted by insertion of a SA-IRES-lacZ-neomycin cassette (tm1e allele), (B) Total RNA prepared from muscle of $\mathrm{CT} 1^{+/ \mathrm{y}}$ and $\mathrm{CT} 1^{-/ \mathrm{y}}$ mice was reverse transcribed and then used for PCR amplification with primers specific for CT1 (expected band size: 250 bp). No amplification product for CT1 was observed in knockout mice. (C,D) Macroscopic (on a mm grid scale) and microscopic view of hind limb muscle after LacZ staining indicating CT1 promoter activation.

TABLE 1 | HPLC-analysis of total creatine concentrations (mean \pm SEM) in $\mathrm{CT} 1^{+/ \mathrm{y}}$ and $\mathrm{CT} 1^{-/ \mathrm{y}}$ mice $(n=4$ per tissue) $(t$-test, $* * * P<0.001)$.

\begin{tabular}{lcc}
\hline \multirow{2}{*}{ Tissue } & \multicolumn{2}{c}{ Total creatine (nmol/mg protein) } \\
\cline { 2 - 3 } & \multicolumn{1}{c}{$\mathbf{C T 1}^{+/ \mathbf{y}}$} & $\mathbf{C T 1}^{-/ \mathbf{y}}$ \\
\hline Heart & $64.3 \pm 6.6$ & $4.5 \pm 0.6^{* * *}$ \\
Brain & $72.6 \pm 9.5$ & $22.5 \pm 1.1^{* * *}$ \\
Skeletal muscle (extensor digitorum longus) & $131.9 \pm 6.7$ & $16.1 \pm 5.3^{* * *}$ \\
Skeletal muscle (soleus) & $137.3 \pm 9.9$ & $15.7 \pm 3.8^{* * *}$ \\
Kidney & $12.3 \pm 1.9$ & $11.9 \pm 3.8$ \\
\hline
\end{tabular}

was increased in another mouse model of CT1 deficiency (Russell et al., 2014). Therefore, we studied AGAT and GAMT protein expression in CT1-deficient mice for putative adaptive changes. Quantitative western blot analysis revealed significant upregulation of AGAT expression in kidney and skeletal muscle of $C T 1^{-/ y}$ mice compared to wild-type mice (Figures $2 \mathrm{~A}, \mathbf{B}$ ). Furthermore, well-detectable GAMT expression was unaltered in skeletal muscle of $C T 1^{-/ y}$ mice, whereas GAMT expression in liver was even reduced in $C T 1^{-/ y}$ mice compared with $C T 1^{+/ y}$ mice (Figures 2C,D). However, despite the strong upregulation of AGAT protein expression, our data revealed pronounced reduction of $\mathrm{Cr}$ in skeletal muscle of $C T 1^{-/ y}$ mice. Thus, increased AGAT expression in skeletal muscle does not compensate for the deficiency in skeletal muscle in $C T 1^{-/ y}$ mice.

\section{CT1-Deficient Mice Reveal Reduced Weight, Length, and Body Mass Index}

L-Arginine:glycine amidinotransferase and GAMT deficiency in transgenic mice leads to $\mathrm{Cr}$-dependent failure to thrive with reduced body weight and length (Schmidt et al., 2004; Choe et al., 2013b). Similarly, $C T 1^{-/ y}$ mice were lean, short, and had a markedly reduced body mass index (BMI) compared with $C T 1^{+/ y}$ littermates (Figures 3A-D). $C T 1^{-/ y}$ mice showed consistently lower body weight as early as from the age of 5 weeks (Figure 3E). Overall, $C T 1^{-/ y}$ mice displayed morphometric alterations indicative of severely impaired whole-body energy homeostasis.

\section{Impaired Motor Behavior in CT1-Deficient Mice}

Creatine transporter-deficient mice displayed reduced body tension and severe kyphoscoliosis, suggesting pronounced 
A
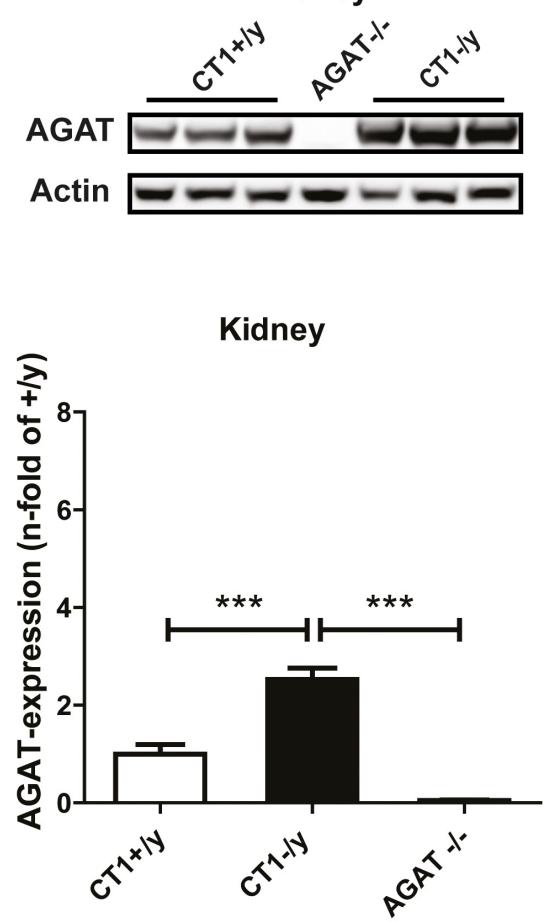

C
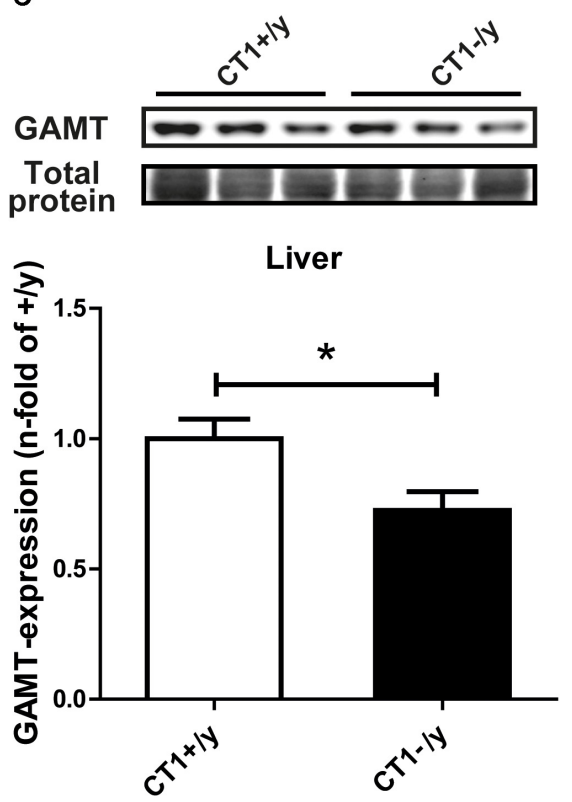

B Muscle
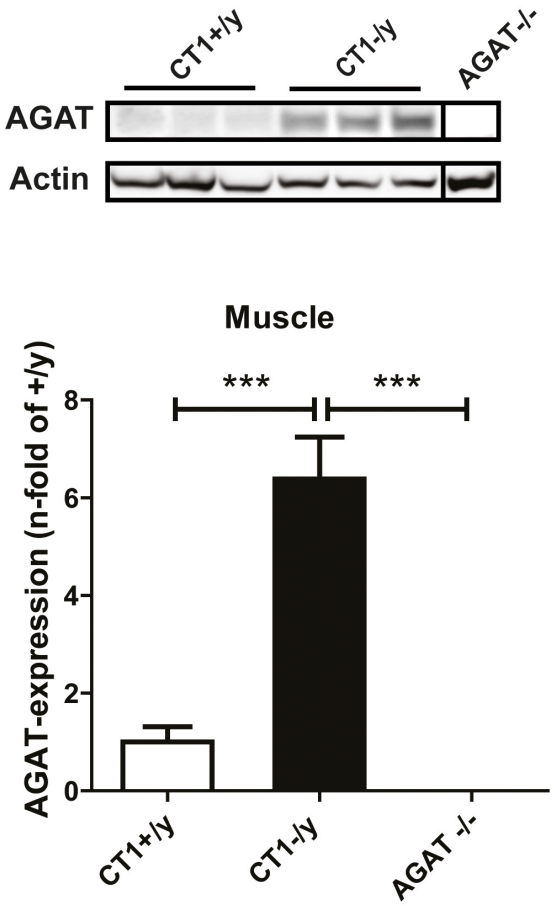

D

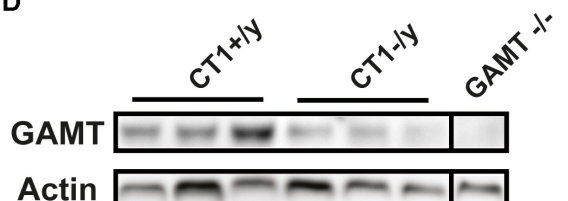

Actin $=m-m$

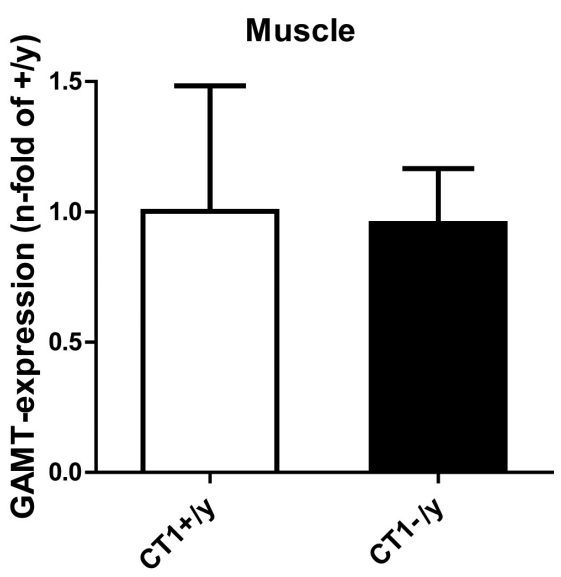

FIGURE 2 | L-Arginine:glycine amidinotransferase and GAMT expression. Relative quantification of AGAT protein levels in kidney (A) and muscle (B) of CT1-/y mice $(n=5-6)$. Relative quantification of GAMT protein levels in liver (C) and muscle (D) of CT1 ${ }^{-/ y}$ mice $(n=6)$. Tissue samples of AGAT ${ }^{-/-}$and GAMT-/- mice to verify antibody specificity $\left({ }^{*} P<0.05 ;{ }^{* * *} P<0.001\right)$.

muscle weakness and chronic muscular hypotonia. Therefore, we analyzed muscle function and motor behavior in detail. Grip strength of $C T 1^{-/ y}$ mice was severely reduced to about $15 \%$ of that of $C T 1^{+/ y}$ littermates (grip strength: $C T 1^{+/ y}$ $1.63 \pm 0.05 \mathrm{mN}, \mathrm{CT}^{-/ \mathrm{y}} 0.25 \pm 0.01 \mathrm{mN}, n=9-15$, Figure 4A). In the rotarod test, latency to fall did not differ between the two groups in the first trial. However, $C T 1^{+/ y}$ littermates showed motor learning and increased performance during subsequent trials, whereas $C T 1^{-/ y}$ mice remained at a constantly low level (Figure 4B). During the pole test, $C T 1^{-/ y}$ mice were not capable of turning upside down, whereas normal performance was observed in almost all $C T 1^{+/ y}$ littermates 


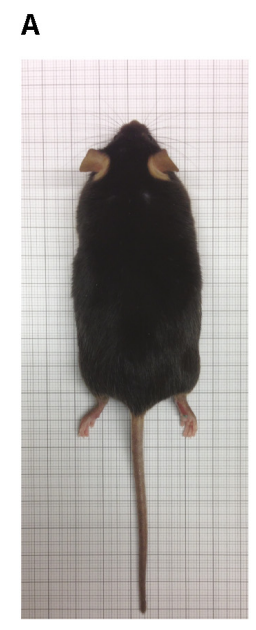

$+/ y$

D

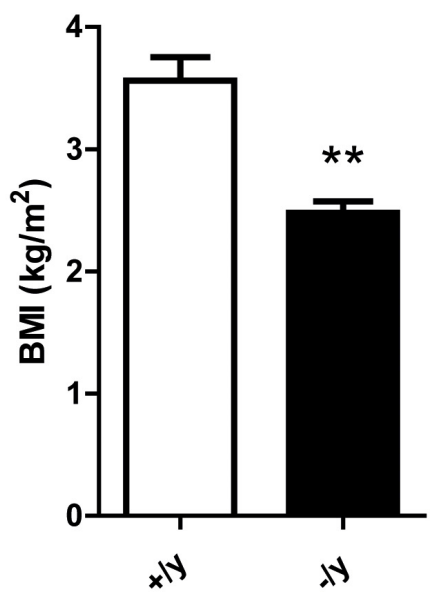

B

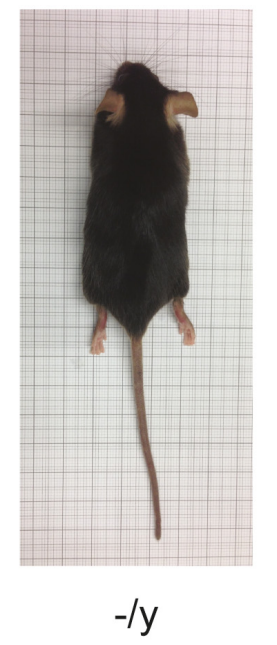

E

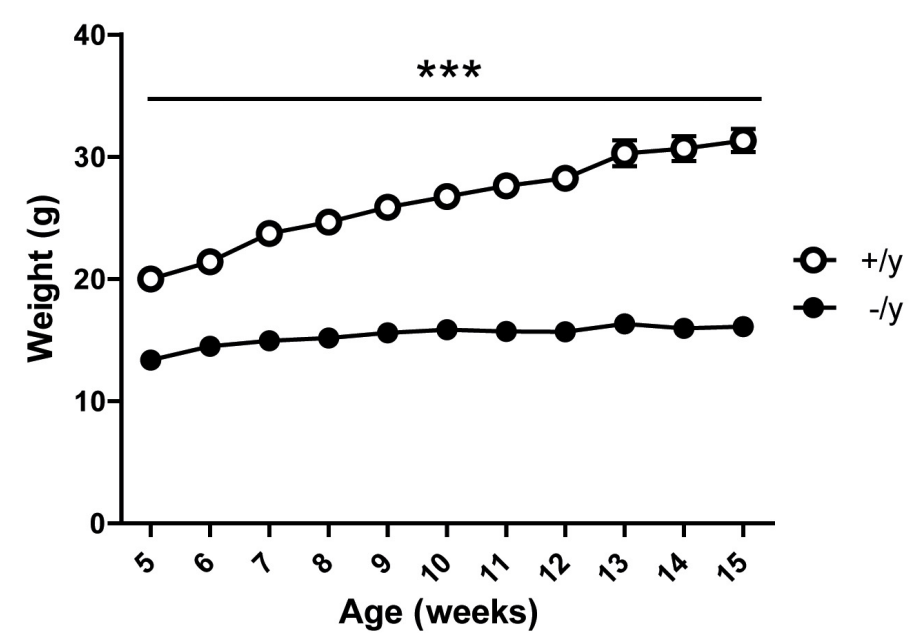

FIGURE 3 | Morphometric parameters of CT1-deficient mice. Representative body morphology (A), snout-anus length (B), weight (C), and BMI (D) of 15-week-old $\mathrm{CT} 1^{+/ \mathrm{y}}$ and $\mathrm{CT} 1^{-/ \mathrm{y}}$ male littermates $(n=5-6)$. (E) Body weight development in male animals until 15 weeks of age $(n=9-15)\left({ }^{* *} P<0.01 ;{ }^{* * *} P<0.001\right)$.

(turning: $C T 1^{+/ y}: 8 / 9$ mice, $C T 1^{-/ y}: 0 / 13$ mice, Figure 4C). In addition to strength, motor learning, and coordination, we analyzed running endurance using an adapted voluntary wheelrunning system (De Bono et al., 2006). In contrast to $C T 1^{+/ y}$ mice, the running distance of $C T 1^{-/ y}$ mice was dramatically reduced (running distance: $C T 1^{+/ \mathrm{y}} 8.41 \pm 0.85 \mathrm{~km} / \mathrm{day}, C T 1^{-/ \mathrm{y}}$ $1.99 \pm 0.26 \mathrm{~km} /$ day, average of days 15-29, Figure 4D). Taken together, $C T 1^{-/ y}$ mice displayed a motor phenotype characterized by severe muscular hypotonia and kyphoscoliosis, reduced muscle strength and low running endurance.

\section{Muscle Atrophy in CT1-Deficient Mice}

We analyzed the underlying cause of impaired motor function of $C T 1^{-/ y}$ mice at MRI and histological levels. MRI of the hind leg revealed reduced muscle CSAs in $C T 1^{-/ y}$ mice $\left(C T 1^{+/ y}\right.$ $83.9 \pm 3.0 \mathrm{~mm}^{2}, C T 1^{-/ y} 51.0 \pm 3.0 \mathrm{~mm}^{2}, n=4-5$, Figures $\left.5 \mathbf{A}, \mathbf{B}\right)$.
We then performed muscle histology to look if potential cell loss or atrophy explains reduced muscle size. Single fiber atrophy was detected in the extensor digitorum longus muscle, where quantitative analysis revealed reduced myocyte CSAs in $C T 1^{-/ y}$ mice compared with $C T 1^{+/ y}$ mice $\left(C T 1^{+/ y} 1466 \pm 171.4 \mu \mathrm{m}^{2}\right.$, $C T 1^{-/ y} 524.6 \pm 22.86 \mu \mathrm{m}^{2}, n=3$, Figures 5C,D). Given that $C T 1^{-/ y}$ mice have severe thoracolumbar kyphosis and reduced muscle force during grip strength testing, both muscle dysfunction and atrophy are likely to be present in all major muscle groups.

\section{CT1 Deficiency Improves Glucose Tolerance}

In a previous study, we detected a pronounced metabolic phenotype in Cr-deficient $\mathrm{AGAT}^{-/-}$mice that was characterized by improved glucose tolerance and resistance to diet-induced 

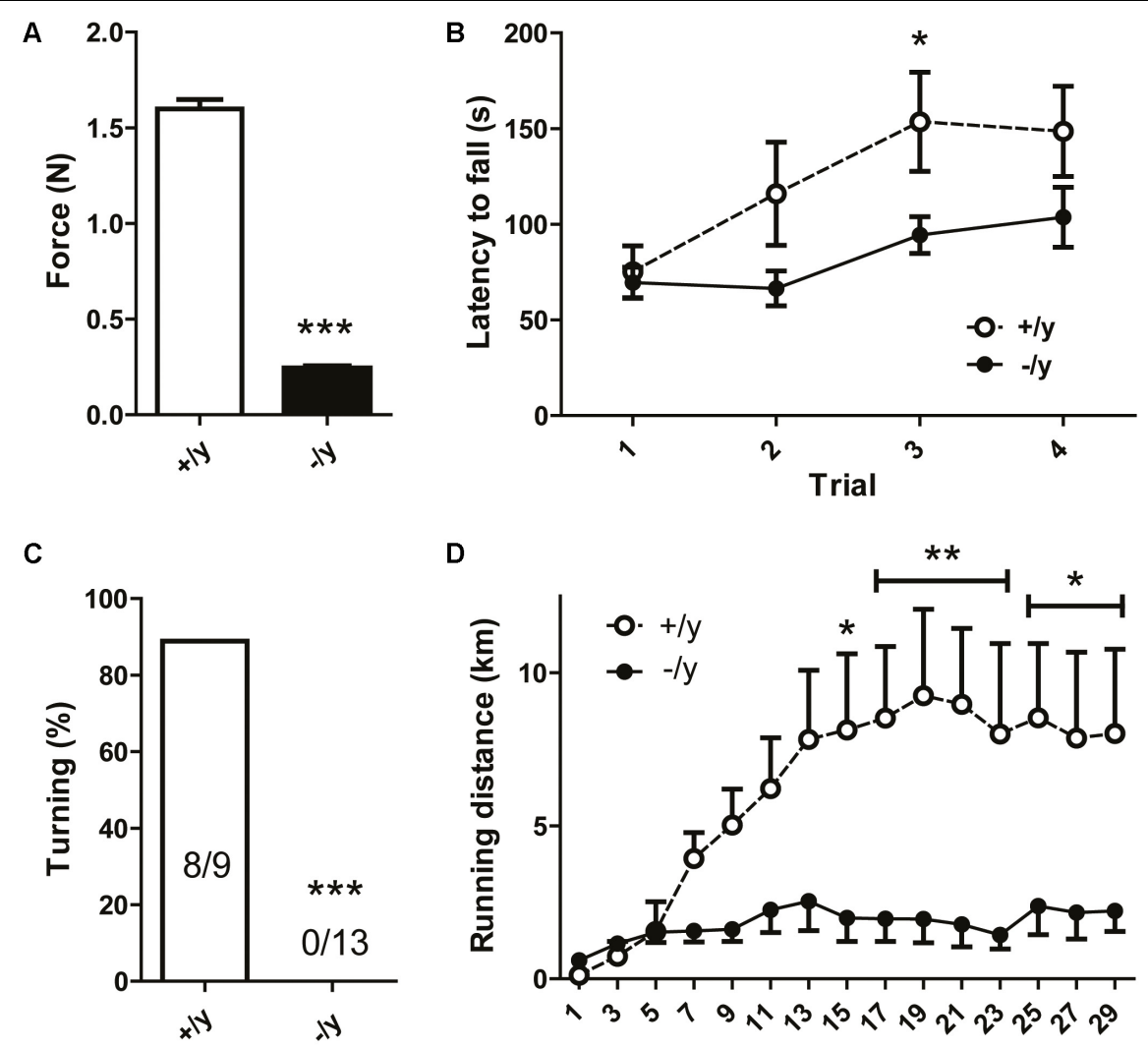

Time (days)

FIGURE 4 | Motor and behavioral phenotype of CT1-deficient mice. Grip strength (A), rotarod performance (B), successful turning in pole test (C), and voluntary running distance (D) of $\mathrm{CT} 1^{+/ \mathrm{y}}$ and $\mathrm{CT} 1^{-/ \mathrm{y}}$ male littermates $(n=9-15)\left({ }^{*} P<0.05\right.$; $\left.^{* *} P<0.01{ }^{* * *} P<0.001\right)$.

obesity (Choe et al., 2013b). Reduced body weight and altered muscle physiology suggested similar metabolic alterations in $C T 1^{-/ y}$ mice. Indeed, fasted and fed blood glucose levels in $C T 1^{-/ y}$ mice were significantly decreased (fasted: $C T 1^{+/ y}$ $128.4 \pm 4.67 \mathrm{mg} / \mathrm{dl}, C T 1^{-/ y} 71.13 \pm 3.14 \mathrm{mg} / \mathrm{dl}$, fed: $C T 1^{+/ \mathrm{y}}$ $152.3 \pm 8.11 \mathrm{mg} / \mathrm{dl}, C T 1^{-/ y} 122.9 \pm 6.08 \mathrm{mg} / \mathrm{dl}$, Figures 6A,B). Furthermore, glucose tolerance tests revealed faster glucose clearance in $C T 1^{-/ y}$ mice compared to $C T 1^{+/ y}$ mice after normalization to fasted blood glucose levels (Figure 6C). As a large proportion of glucose is taken up into skeletal muscle, we analyzed the steady-state levels of glucose transporter protein type 4 in skeletal muscle. Quantitative western blot analysis revealed significantly increased GLUT4 levels in $C T 1^{-/ y}$ mice (Figure 6D), which explains faster glucose clearance. In addition, we detected reduced expression levels of UCP3 and a trend toward increased COX4 expression indicating facilitated oxidative phosphorylation (Figure 6D). Furthermore, citrate synthase activity - a measure of mitochondrial mass was significantly increased in extensor digitorum longus and soleus muscle (Figure 6E). These findings suggest mitochondrial content is increased to accelerate energy production to meet increased energy demand. Given the imbalance between energy demand and production, we looked for the activation of AMPK, a key metabolic energy sensor and switch. Similar to GAMT and AGAT mice, AMPK activation, as measured by phosphoAMPK (pAMPK) or phosphorylated substrate (pACC) levels, was increased in $C T 1^{-/ y}$ mice indicating a chronic catabolic state, possibly resulting from energy deficiency, in skeletal muscle (Figure 6F).

\section{Reduced Phosphocreatine Levels and Altered Muscle Energy Metabolism in CT1-Deficient Mice}

Our data indicate profound metabolic changes in muscle of CT1deficient mice. Therefore, we used muscle ${ }^{31} \mathrm{P}$ MR spectroscopy to obtain functional data on high energy phosphate turnover. $C T 1^{-/ y}$ mice demonstrated a strong reduction of $\mathrm{PCr}$ in skeletal muscle (Figure 7A). The $\mathrm{PCr} / \mathrm{P}_{\mathrm{i}}$ ratio was significantly reduced in $C T 1^{-/ y}$ mice compared with $\mathrm{CT} 1^{+/ \mathrm{y}}$ mice $\left(\mathrm{CT} 1^{+/ \mathrm{y}}: 12.2 \pm 0.7\right.$, $\mathrm{CT}^{-/ \mathrm{y}}: 0.09 \pm 0.02, P<0.001$, Figure 7B). Estimation of $\mathrm{PCr}$ tissue concentrations in skeletal muscle revealed a 40 -fold reduction in $C T 1^{-/ y}$ mice $\left(C T 1^{+/ y}: 25.4 \pm 0.1 \mathrm{mM}, C T 1^{-/ y}\right.$ : $0.6 \pm 0.1 \mathrm{mM}, P<0.001)$. In contrast to this decrease, the $\mathrm{Pi}$ tissue concentration in skeletal muscle of $\mathrm{CT} 1^{-/ y}$ mice was increased threefold $\left(C T 1^{+/ y}: 2.16 \pm 0.22 \mathrm{mM}, C T 1^{-/ y}\right.$ : $6.6 \pm 0.3 \mathrm{mM}, P<0.001)$. Furthermore, we determined whether ATP levels were decreased in the hind limb of $\mathrm{CT} 1^{-/ y}$ mice by 
A $+/ y$
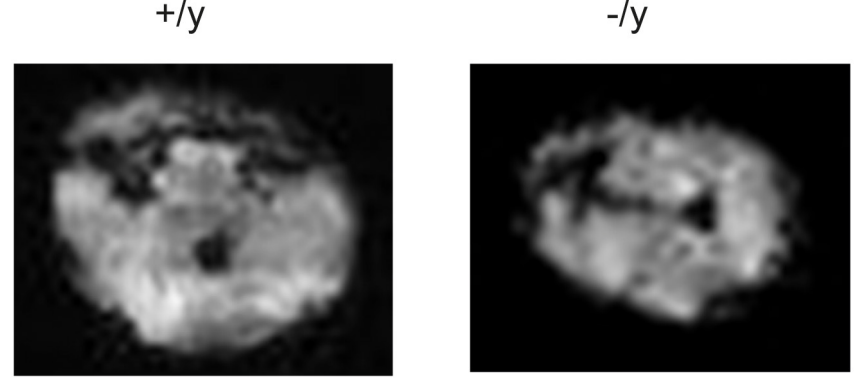

C

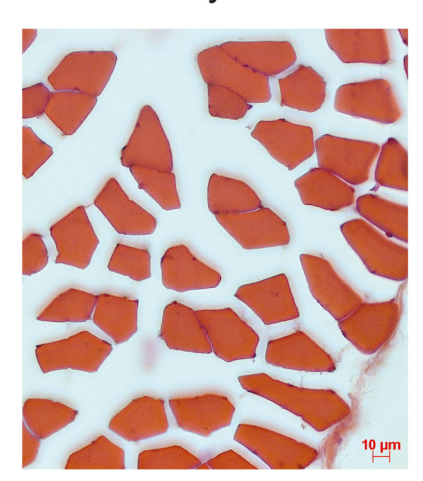

B

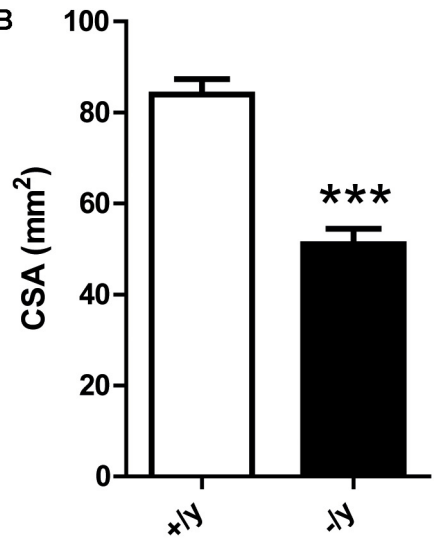

D

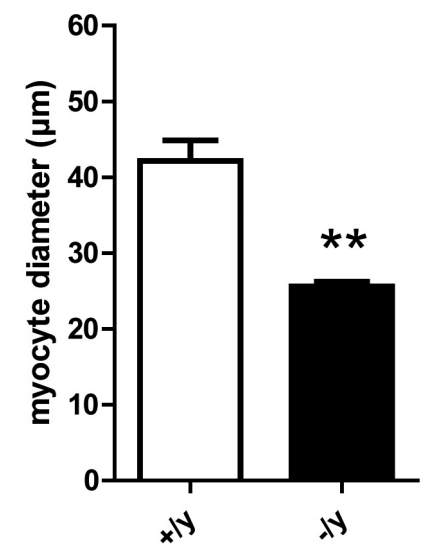

FIGURE 5 | Muscle morphology and histology of CT1-deficient mice. (A) MR images for gross morphological analysis of hind limb muscles. (B) Cross-sectional area of hind limb muscle $\left(n=4-5,{ }^{* * *} P<0.001\right)$ determined by MRI. (C) Representative histological staining of extensor digitorum longus muscle. (D) Myocyte diameter of extensor digitorum longus muscle $(n=3, * * P<0.01)$.

evaluating the signal intensity of ATP relative to the muscle CSA (Nabuurs et al., 2013). Assuming a tissue concentration of $7.8 \mathrm{mM}$ in wild-type skeletal muscle (in 't Zandt et al., 2003), the ATP concentration in $\mathrm{CT} 1^{-/ \mathrm{y}}$ hind limb muscle was estimated to be $4.2 \pm 1.2 \mathrm{mM}$ and therefore decreased by more than $40 \%$. ATP $/ \mathrm{P}_{\mathrm{i}}$ ratios were significantly reduced in $\mathrm{CT}^{-/ y}$ mice, indicating abnormal energy metabolism by contributing to a decreased resting state phosphorylation potential due to the depletion of PCr stores $\left(C T 1^{+/ \mathrm{y}}: 3.87 \pm 0.16, C T 1^{-/ \mathrm{y}}: 0.77 \pm 0.06, P<0.001\right.$, Figures $7 \mathrm{C}-\mathrm{E})$. The calculated in vivo tissue $\mathrm{pH}$ was unaltered between $C T 1^{+/ y}$ and $C T 1^{-/ y}$ mice. Next, we assessed kinetics of ATP synthase in resting skeletal muscle from ST experiments. The forward rate $k_{\mathrm{f}}$ of ATP synthases in skeletal muscle of $C T 1^{-/ y}$ mice was increased compared with $C T 1^{+/ y}$ mice, but did not reach statistical significance $\left(C T 1^{+/ y}: 0.20 \pm 0.04 \mathrm{~s}^{-1}\right.$, $C T 1^{-/ y}: 0.25 \pm 0.05 \mathrm{~s}^{-1}, P=0.13$ ) (Figure 7F). The trend toward increased $k_{\mathrm{f}}$ of ATP synthase in $C T 1^{-/ y}$ mice indicates increased total cytosolic and mitochondrial ATP synthetase activity. Given the increased Pi tissue concentration in $\mathrm{CT1}^{-1 \mathrm{y}}$ mice, the $\mathrm{Pi} \rightarrow \mathrm{ATP}$ flux is increased in $C T 1^{-/ \mathrm{y}}$ mice compared with $C T 1^{+/ y}$ mice $\left(C T 1^{+/ y}: 0.43 \pm 0.08 \mathrm{mM} \mathrm{s}^{-1}, C T 1^{-/ y}\right.$ :
$1.6 \pm 0.3 \mathrm{mM} \mathrm{s}^{-1}, P<0.001$ ) (Figure 7G). But, increased $\mathrm{Pi} \rightarrow$ ATP flux as a parameter of total ATP synthase activity at rest is not sufficient to compensate for reduced ATP levels in the absence of PCr. Taken together, changes in muscle function and morphology of $\mathrm{CT1}^{-/ y}$ mice were associated with marked alterations in energy metabolism, emphasizing the critical role of CT1 in muscle physiology.

\section{DISCUSSION}

Our study revealed that CT1-deficient mice have a strongly reduced skeletal muscle $(\mathrm{P}) \mathrm{Cr}$, an impaired motor function with severe muscle atrophy, and increased glucose metabolism due to AMPK activation. Major clinical problems in CT1deficient patients include behavioral abnormalities, seizures, and intellectual impairment (Stockler et al., 2007). Therefore, previous research was mainly focused on the effects of $\mathrm{Cr}$ depletion in brain. In all available Cr-deficient mouse models, however, pronounced muscular phenotypes were observed (Schmidt et al., 2004; Nabuurs et al., 2013; Baroncelli et al., 2014; 


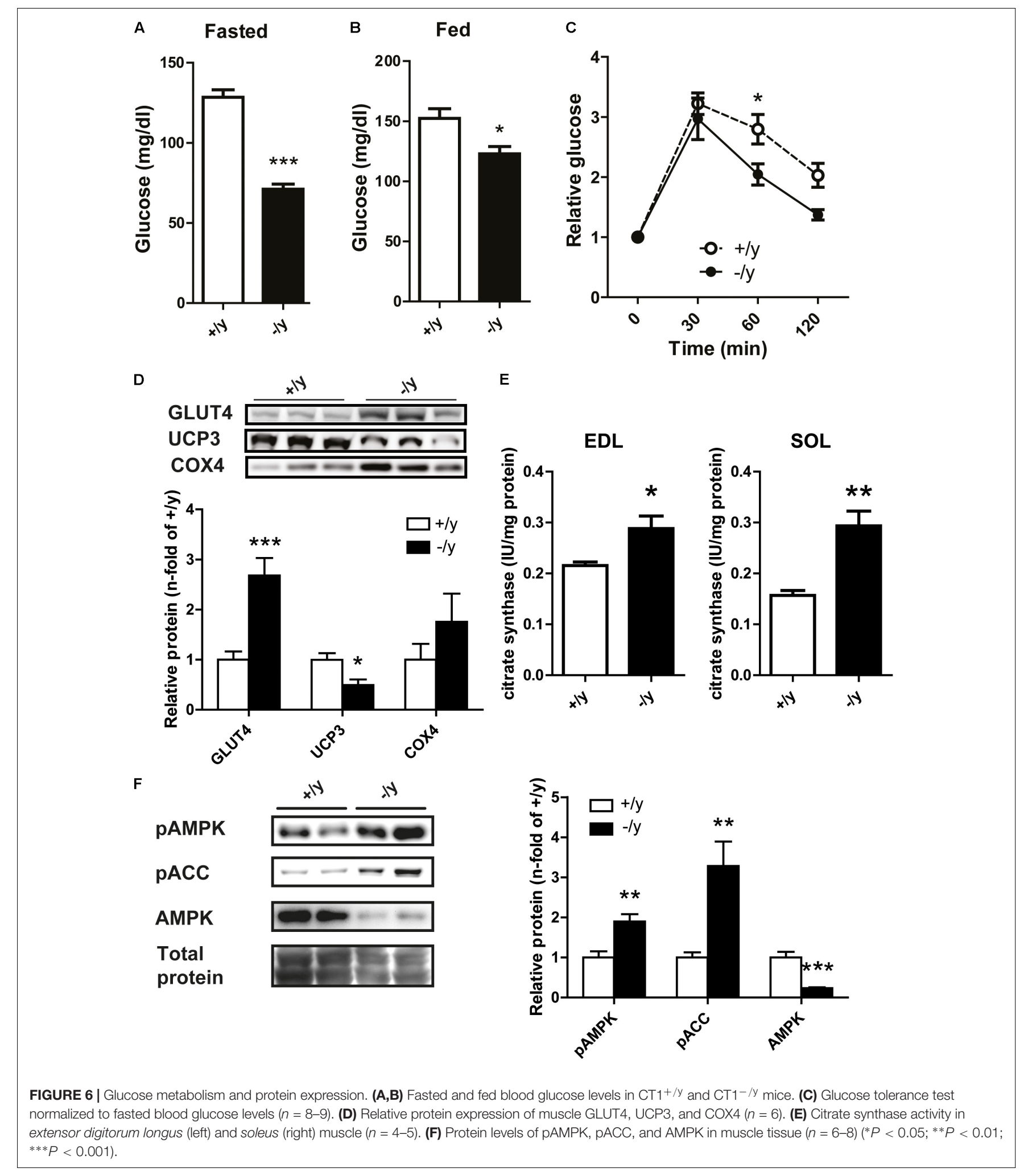

Russell et al., 2014). Here, we demonstrate strongly reduced PCr levels in skeletal muscle of CT1-deficient mice resulting in chronic energy depletion with increased resting Pi/ATP ratios. Muscle physiology, metabolism, and morphology were severely affected in CT1-deficient mice resulting in muscular atrophy and thoracolumbar scoliosis.

Following synthesis in liver and kidney, Cr delivery to its target organs such as muscle and brain is dependent on active 
A
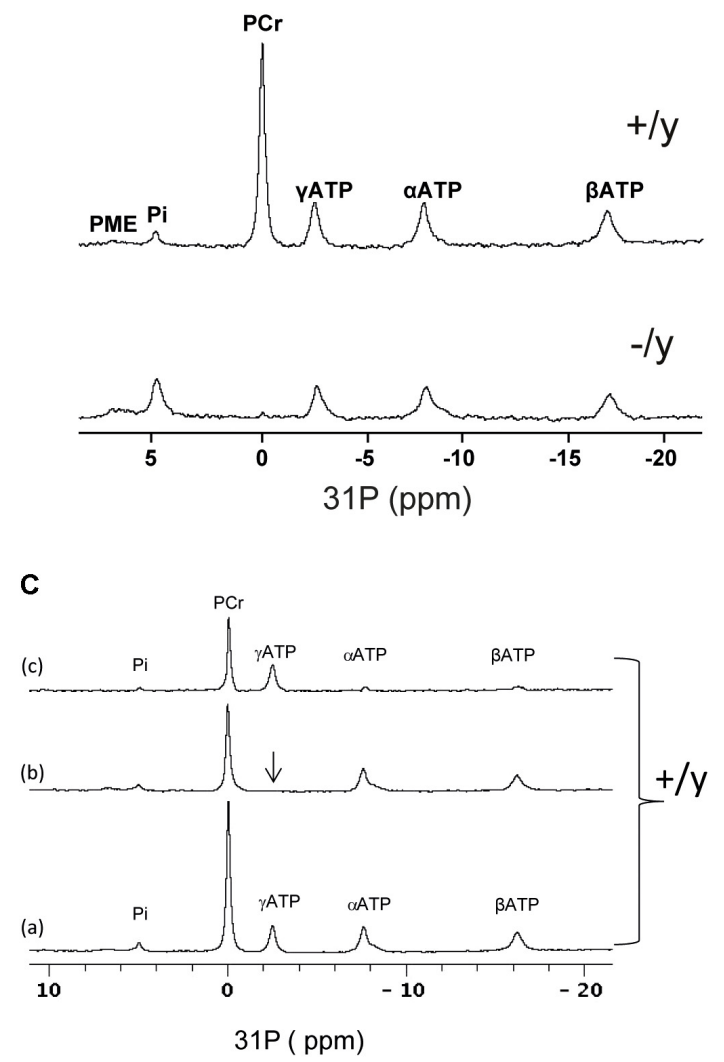

E

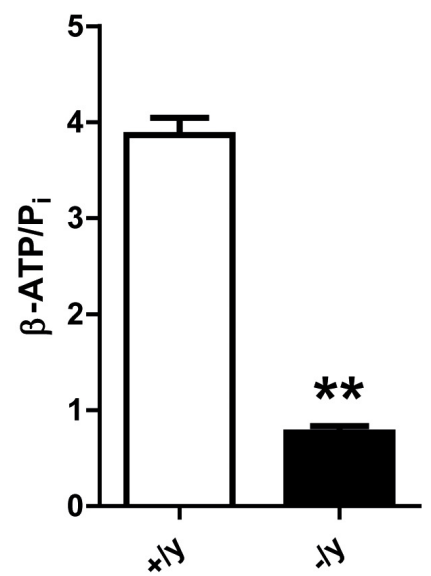

$\mathbf{F}$

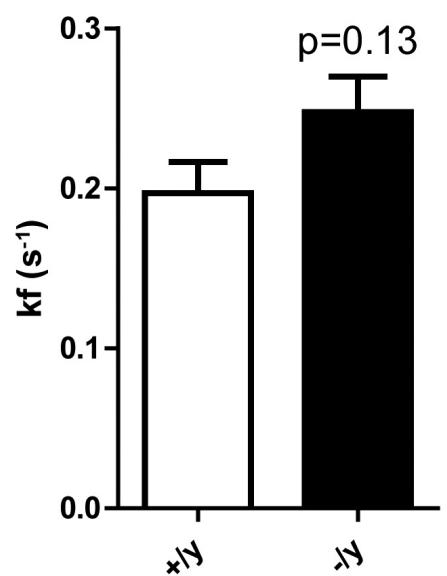

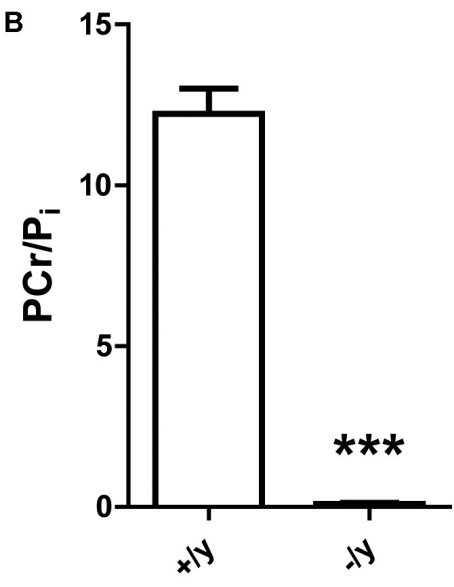

D

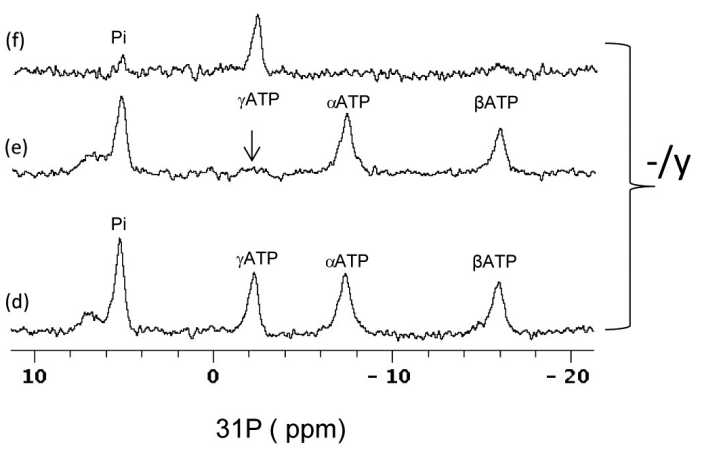

G

FIGURE 7 | Muscle energy metabolism. (A) Representative ${ }^{31} \mathrm{P}$ MR spectra of hind limb muscle in $\mathrm{CT} 1^{+/ \mathrm{y}}$ and $\mathrm{CT} 1^{-/ y}$ mice (PCr, phosphocreatine; $\mathrm{Pi}$, inorganic phosphate; PMEs, phosphomonoesters; ppm, parts per million). (B) PCr/Pi ratios in CT1 $1^{+/ y}$ and CT1 $1^{-/ y}$ mice measured with ${ }^{31} \mathrm{P}$ MR spectroscopy $(n=4-5)$. (C,D) Saturation transfer ${ }^{31} \mathrm{P}$ MRS experiments on hind limb muscle of $\mathrm{CT} 1^{+/ y} \mathbf{( A )}$ and CT1 ${ }^{-/ y}$ mice (B) to assess the Pi $\rightarrow$ ATP kinetics. The $\gamma$ ATP peak is saturated (b) and this saturation is transferred to the PCr and Pi peaks due to the creatine kinase and ATPase activity (subtraction spectra $\mathrm{c}=\mathrm{a}$ minus b). This effect was used to calculate the forward rate constant $k_{f}$. ATP to free phosphate ratios (ATP/Pi) $(\mathbf{E}), k_{f}$ values $(\mathbf{F})$, and phosphate $\left(\mathrm{Pi} \rightarrow\right.$ ATP) flux $(\mathbf{G})$ of hind limb muscle in CT1 $1^{+/ y}$ and CT1 $1^{-/ y}$ mice assessed with MR spectroscopy $(n=4-5)\left(*^{*} P<0.01 ; * * * P<0.001\right)$.

transporters. To date, only CT1 encoded by SLC6A8 has been identified as effective $\mathrm{Cr}$ transporter across cell membranes (Abplanalp et al., 2013; van de Kamp et al., 2014). Consequently, impaired CT1 activity has been associated with reduced cerebral and muscular Cr levels (deGrauw et al., 2003; van de Kamp et al., 2013). Here, we show that CT1 deficiency leads to markedly 
reduced $\mathrm{Cr}$ levels detected by HPLC-analysis and even stronger reduced $\mathrm{PCr}$ levels with in vivo ${ }^{31} \mathrm{P}$ MR spectroscopy in skeletal muscle (Figures 1, 7). In previous studies on muscle of CT1deficient mice, however, residual $\mathrm{Cr}$ was reported from below detection limit up to 23 or $36 \%$ of wild-type levels (Skelton et al., 2011; Russell et al., 2014; Baroncelli et al., 2016). In addition, two case studies on CT1-deficient patients showed almost normal levels of $\mathrm{Cr}$ in skeletal muscle (deGrauw et al., 2003; PyneGeithman et al., 2004). These discrepancies in muscular Cr content might be explained by residual CT1 activity in affected human patients (depending on the molecular nature of the mutation) or by mouse strain differences. The differences in Cr levels might also be due to specific detection techniques. Photometric assays can be unspecific and overestimate $\mathrm{Cr}$ values (Skelton et al., 2011; Russell et al., 2014).

An alternative explanation for residual $\mathrm{Cr}$ levels in muscle and brain of CT1-deficient animals as well as patients might be endogenous $\mathrm{Cr}$ synthesis. Under healthy or normal physiological conditions, AGAT levels are low in skeletal muscle (Figure 2). Cr synthesis is thought to take place almost exclusively in liver and kidney, with a minor contribution from pancreas (Wyss and Kaddurah-Daouk, 2000; Brosnan and Brosnan, 2010; da Silva et al., 2014). However, AGAT expression is regulated by $\mathrm{Cr}$ availability in a negative feedback loop (Choe et al., 2013a; Russell et al., 2014). Indeed, we detected increased AGAT expression in skeletal muscle following intracellular Cr depletion due to CT1 deficiency (Figure 2). As PCr levels remained low despite GAMT and increased AGAT expression, endogenous $\mathrm{Cr}$ synthesis in muscle was insufficient to compensate for CT1 deficiency in our mouse model. Thus, CT1 deficiency in mice induces a strong decrease in $\mathrm{Cr}$ in muscle, despite compensatory upregulation of enzymes involved in Cr synthesis.

Skeletal muscle contains $\mathrm{Cr}$ in concentrations of up to $40 \mathrm{mM}$. Accordingly, muscle physiology was severely affected in $\mathrm{Cr}$ deficient $\mathrm{CT}^{-/ y}$ mice. Reduced muscle force and endurance as well as pronounced kyphoscoliosis demonstrate generalized impairment of muscle function (Figure 5). These functional alterations were accompanied by structural changes such as a reduction in muscle and myocyte diameter, which is in line with reports describing a close correlation of muscle diameter and contractile power (Maughan et al., 1983a,b). Absolute numbers of myocytes were not quantified, but similar reductions in muscle and myocyte diameters do not suggest a reduction in the overall number of myocytes. A reduced myocyte diameter can be explained by Cr deficiency itself and by chronic energy depletion and involvement of catabolic pathways including AMPK activation. Previous studies on AGATand GAMT-deficient mice showed ultrastructural changes in muscle histology, including lipid droplets around mitochondria (Schmidt et al., 2004; Nabuurs et al., 2013). Also AGATdeficient muscle displayed a transcriptomic signature resembling a transcriptional response known as the mitochondrial unfolded protein response (Stockebrand et al., 2016; Shpilka and Haynes, 2018). Neither ultrastructural analysis of skeletal muscle nor transcriptomic analyses have been performed in CT1deficient mice yet, but similar processes are likely to be involved.
Motor behavior in CT1-deficient mice was impaired not only in terms of muscle force but also wheel running distance and motor learning (Figure 5). Reduced wheel running might partly be explained by low muscle force, but also by deficient energy stores and impaired oxidative phosphorylation (see below). During rotarod testing for motor learning and coordination, performance during the first trial did not differ from $\mathrm{CT}^{+/ y}$ mice because low body weight might compensate for reduced muscle strength. However, unlike $\mathrm{CT} 1^{+/ y}$ mice, the performance of $\mathrm{CT}^{-/ y}$ mice did not improve during subsequent trials indicating not only peripheral muscular but also CNS contribution to the motor phenotype.

Severely altered structure and function of skeletal muscle were also observed in Cr-deficient AGAT knockout mice, whereas GAMT knockout mice displayed a milder muscular phenotype most likely due to high levels of guanidinoacetate that, although being a weak substrate for creatine kinase, can be phosphorylated and partly substitute for Cr (Schulze et al., 2003; Ensenauer et al., 2004; Kan et al., 2004). Some muscle properties derived from ${ }^{31} \mathrm{P}$ MRS data show strikingly similar differences with WT between AGAT and CT1 knockouts: in both PCr was dramatically reduced with a concomitant decrease of ATP by $40 \%$. This resulted in a metabolic remodeling including a fourfold increased Pi/ATP at an unchanged tissue $\mathrm{pH}$ (Nabuurs et al., 2013). The observed stronger reduction in PCr (40-fold) than in total $\mathrm{Cr}$ (10-fold) would be in agreement with a creatine kinase equilibrium shift due to the lower ATP level. Apparently, despite increased $\mathrm{Pi} \rightarrow \mathrm{ATP}$ flux the muscles of $\mathrm{CT}^{-/ y}$ mice cannot maintain normal ATP levels, even in the resting state. Reduced ATP and increased Pi levels result in chronic AMPK activation indicating a catabolic state favoring energy production. Accordingly, mitochondrial volume is increased and oxidative phosphorylation is accelerated, but not sufficient to normalize ATP levels. In line with these findings, creatine-deficient muscle in $\mathrm{AGAT}^{-/-}$mice revealed increased absolute mitochondrial mass, but decreased respiratory chain enzyme activities per mitochondrial content (i.e., citrate synthase activity) (Nabuurs et al., 2013).

Both functional (reduction in grip strength: $70 \%$ for $\mathrm{AGAT}^{-/-}$vs. $85 \%$ in $\mathrm{CT}^{-/ y}$ ) and structural changes (reduction in myocyte diameter: $35 \%$ for $\mathrm{AGAT}^{-/-}$vs. $65 \%$ in $\mathrm{CT}^{-/ y}$ ) were even more pronounced in $\mathrm{CT} 1^{-/ y}$ mice compared with $\mathrm{AGAT}^{-/-}$mice (Figures 4A, 5D) (Nabuurs et al., 2013). PCr levels in adult mice measured by MRS were low both in $\mathrm{AGAT}^{-/-}$and $\mathrm{CT}^{-/ \mathrm{y}}$ mice and cannot explain the differences. However, it has to be considered that mice from both lines were exposed to high maternal $\mathrm{Cr}$ levels during pregnancy and lactation. In $\mathrm{AGAT}^{-/-}$mice, $\mathrm{Cr}$ can be taken up into the target organs by CT1 and may compensate for deficient endogenous $\mathrm{Cr}$ synthesis to a certain extent. In CT1 deficiency, a lack of functional $\mathrm{Cr}$ transporters prevents normalization of $\mathrm{Cr}$ stores in muscle, even following high serum $\mathrm{Cr}$ levels throughout intrauterine and postnatal development. Hence, intracellular $\mathrm{Cr}$ deficiency during early development seems to play a critical role for the outcome of genetic Cr deficiency.

Cerebral creatine deficiency in mice resulted in cognitive impairment and neuropathological abnormalities, which might 
also contribute to the muscle phenotype of systemic CT1deficient mice (Kurosawa et al., 2012; Baroncelli et al., 2016). But skeletal muscle of mouse models deficient in muscle creatine kinase lacked burst activity, revealed altered intracellular calcium release and increased fatigue with tetanic stimulation (van Deursen et al., 1993; Steeghs et al., 1997, 1998; Dahlstedt et al., 2000). In the absence of PCr/Cr buffering, in vivo MRS studies of muscle energetics revealed that ATP levels, $\mathrm{pH}$ and Pi levels could not be maintained during ischemic conditions despite increased glycolytic ATP synthesis (in 't Zandt et al., 1999, 2003; Nabuurs et al., 2013). Therefore, creatine deficiency in skeletal muscle per se impairs energy metabolism and motor function independent of neuronal dysfunction.

Limitations of our study are that we cannot rule out that developmental alterations are also responsible for impaired motor function. Given that mice with CT1 deficiency revealed age-related progressive cognitive impairment associated with brain aging, motor behavior could also be altered due to developmental disturbances (Baroncelli et al., 2016). Furthermore, in our systemic CT1-deficient mouse models, we are unable to clearly differentiate neuronal and muscular contributions to motor function. Given that brain-specific CT1 deficiency in mice recapitulates some metabolic and cognitive characteristics, a contribution of neuronal creatine deficiency to motor function is possible (Kurosawa et al., 2012; Baroncelli et al., 2016). But other mouse models with disrupted $\mathrm{PCr} / \mathrm{Cr}$ buffering (i.e., deficiency of AGAT, cytosolic or mitochondrial creatine kinase) clearly link muscle creatine deficiency with motor dysfunction.

Although cognitive impairment and developmental delay are the hallmarks of human $\mathrm{Cr}$ deficiency syndromes, muscular hypotonia and myopathy were also described in patients with AGAT, GAMT, and CT1 deficiency (Stockler et al., 1996; Anselm et al., 2006; Nouioua et al., 2013). The overt muscular phenotype in Cr-deficient mouse models, however, has not been observed in humans. In contrast to mice, human patients still ingest $\mathrm{Cr}$ via their normal diet. However, oral $\mathrm{Cr}$ supplementation is only feasible in AGAT and GAMT deficiency, but proved to be ineffective in CT1 deficiency (Stockler et al., 2007). Expression of AGAT is upregulated in muscle of CT1-deficient mice (Figure 2). It is possible that this compensatory mechanism is sufficient to maintain endogenous $\mathrm{Cr}$ synthesis in human patients. To our knowledge, AGAT and GAMT expression in patients has not yet been directly assessed, for example by muscle biopsy. Although impaired skeletal muscle function does not seem to be a

\section{REFERENCES}

Abplanalp, J., Laczko, E., Philp, N. J., Neidhardt, J., Zuercher, J., Braun, P., et al. (2013). The cataract and glucosuria associated monocarboxylate transporter MCT12 is a new creatine transporter. Hum. Mol. Genet. 22, 3218-3226. doi: $10.1093 / \mathrm{hmg} / \mathrm{ddt} 175$

Anselm, I. A., Alkuraya, F. S., Salomons, G. S., Jakobs, C., Fulton, A. B., Mazumdar, M., et al. (2006). X-linked creatine transporter defect: a report on two unrelated boys with a severe clinical phenotype. J. Inherit. Metab. Dis. 29, 214-219. doi: 10.1007/s10545-0060123-4 critical symptom in most CT1-deficient patients, low intracellular $\mathrm{PCr} / \mathrm{Cr}$ energy stores might further compromise muscle function and increase the risk of muscle damage in situations of metabolic stress such as infections or intensified exercise in CT1-deficient patients. In summary, CT1 deficiency results in reduced levels of high energy phosphates (PCr, ATP), muscle weakness and atrophy, despite compensatory mechanisms of creatine and ATP biosynthesis.

\section{AUTHOR CONTRIBUTIONS}

MS and C-UC conceived the concept and designed the work. MS, AS, SH, DI, HL, CL, AN, and C-UC designed, conducted and analyzed metabolic phenotyping, and molecular biology experiments. DD and AH designed, conducted, and analyzed the MRS-experiments. MS and IH-B generated CT1 knockout mice. AS and C-UC designed, conducted, and analyzed behavioral experiments. MS and C-UC drafted the work. All authors critically revised the manuscript, approved the final version of the manuscript, and agree to be accountable for all aspects of the work. All persons designated as authors qualify for authorship, and all those who qualify for authorship are listed.

\section{FUNDING}

This work was supported by the Deutsche Forschungsgemeinschaft (DFG) (Grant No. CH872/1-1, C-UC, AN, DI) and the Werner-Otto-Stiftung (5/86, C-UC). The MR experiments were part of a proof of concept project in Euro-Bioimaging and supported by Netherlands Organization for Scientific Research (Grant No. CSBR09/013V). HPLC measurements were supported by a British Heart Foundation program (Grant No. RG/13/8/30266).

\section{ACKNOWLEDGMENTS}

We wish to thank H. Voss for expert animal care, S. Schillemeit for genotyping and tissue sectioning and F. Morellini for help with behavioral studies. A. Veltien is acknowledged for maintaining the MR instrument. We also thank the EUCOMM consortium for providing the ES cell clone used to generate the knock out model.

Baroncelli, L., Alessandri, M. G., Tola, J., Putignano, E., Migliore, M., Amendola, E., et al. (2014). A novel mouse model of creatine transporter deficiency. F1000Res 3:228. doi: 10.12688/f1000research.5369.1

Baroncelli, L., Molinaro, A., Cacciante, F., Alessandri, M. G., Napoli, D., Putignano, E., et al. (2016). A mouse model for creatine transporter deficiency reveals early onset cognitive impairment and neuropathology associated with brain aging. Hum. Mol. Genet. 25, 4186-4200. doi: 10.1093/hmg/ ddw252

Brosnan, J. T., and Brosnan, M. E. (2010). Creatine metabolism and the urea cycle. Mol. Genet. Metab. 100(Suppl. 1), S49-S52. doi: 10.1016/j.ymgme.2010. 02.020 
Choe, C. U., Atzler, D., Wild, P. S., Carter, A. M., Boger, R. H., Ojeda, F., et al. (2013a). Homoarginine levels are regulated by L-arginine:glycine amidinotransferase and affect stroke outcome: results from human and murine studies. Circulation 128, 1451-1461. doi: 10.1161/CIRCULATIONAHA.112. 000580

Choe, C. U., Nabuurs, C., Stockebrand, M. C., Neu, A., Nunes, P., Morellini, F., et al. (2013b). L-arginine:glycine amidinotransferase deficiency protects from metabolic syndrome. Hum. Mol. Genet. 22, 110-123. doi: 10.1093/hmg/dds407

da Silva, R. P., Clow, K., Brosnan, J. T., and Brosnan, M. E. (2014). Synthesis of guanidinoacetate and creatine from amino acids by rat pancreas. Br. J. Nutr. 111, 571-577. doi: 10.1017/S0007114513003012

Dahlstedt, A. J., Katz, A., Wieringa, B., and Westerblad, H. (2000). Is creatine kinase responsible for fatigue? Studies of isolated skeletal muscle deficient in creatine kinase. FASEB J. 14, 982-990. doi: 10.1096/fasebj.14.7.982

Daly, M. M. (1985). Guanidinoacetate methyltransferase activity in tissues and cultured cells. Arch. Biochem. Biophys. 236, 576-584. doi: 10.1016/00039861(85)90661-7

De Bono, J. P., Adlam, D., Paterson, D. J., and Channon, K. M. (2006). Novel quantitative phenotypes of exercise training in mouse models. Am. J. Physiol. Regul. Integr. Comp. Physiol. 290, R926-R934.

deGrauw, T. J., Cecil, K. M., Byars, A. W., Salomons, G. S., Ball, W. S., and Jakobs, C. (2003). The clinical syndrome of creatine transporter deficiency. Mol. Cell Biochem. 244, 45-48. doi: 10.1023/A:1022487218904

Ensenauer, R., Thiel, T., Schwab, K. O., Tacke, U., Stockler-Ipsiroglu, S., Schulze, A., et al. (2004). Guanidinoacetate methyltransferase deficiency: differences of creatine uptake in human brain and muscle. Mol. Genet. Metab. 82, 208-213. doi: 10.1016/j.ymgme.2004.04.005

in 't Zandt, H. J., Oerlemans, F., Wieringa, B., and Heerschap, A. (1999). Effects of ischemia on skeletal muscle energy metabolism in mice lacking creatine kinase monitored by in vivo $31 \mathrm{P}$ nuclear magnetic resonance spectroscopy. NMR Biomed. 12, 327-334. doi: 10.1002/(SICI)1099-1492(199910)12:6<327:: AID-NBM570>3.0.CO;2-9

in 't Zandt, H. J. A., De Groof, A. J. C., Renema, W. K. J., Oerlemans, F. T. J. J., Klomp, D. W. J., Wieringa, B., et al. (2003). Presence of (phospho)creatine in developing and adult skeletal muscle of mice without mitochondrial and cytosolic muscle creatine kinase isoforms. J. Physiol. 548, 847-858. doi: 10.1111/ j.1469-7793.2003.00847.x

Ireland, Z., Russell, A. P., Wallimann, T., Walker, D. W., and Snow, R. (2009). Developmental changes in the expression of creatine synthesizing enzymes and creatine transporter in a precocial rodent, the spiny mouse. BMC Dev. Biol. 9:39. doi: 10.1186/1471-213X-9-39

Kan, H. E., Renema, W. K., Isbrandt, D., and Heerschap, A. (2004). Phosphorylated guanidinoacetate partly compensates for the lack of phosphocreatine in skeletal muscle of mice lacking guanidinoacetate methyltransferase. J. Physiol. 560, 219-229. doi: 10.1113/jphysiol.2004.067926

Koretsky, A. P., Basus, V. J., James, T. L., Klein, M. P., and Weiner, M. W. (1985). Detection of exchange reactions involving small metabolite pools using NMR magnetization transfer techniques: relevance to subcellular compartmentation of creatine kinase. Magn. Reson. Med. 2, 586-594. doi: 10.1002/mrm. 1910020610

Kurosawa, Y., Degrauw, T. J., Lindquist, D. M., Blanco, V. M., Pyne-Geithman, G. J., Daikoku, T., et al. (2012). Cyclocreatine treatment improves cognition in mice with creatine transporter deficiency. J. Clin. Invest. 122, 2837-2846. doi: 10.1172/JCI59373

Mancini, G. M., Catsman-Berrevoets, C. E., De Coo, I. F., Aarsen, F. K., Kamphoven, J. H., Huijmans, J. G., et al. (2005). Two novel mutations in SLC6A8 cause creatine transporter defect and distinctive X-linked mental retardation in two unrelated Dutch families. Am. J. Med. Genet. A 132A, 288-295. doi: 10.1002/ajmg.a.30473

Maughan, R. J., Watson, J. S., and Weir, J. (1983a). Relationships between muscle strength and muscle cross-sectional area in male sprinters and endurance runners. Eur. J. Appl. Physiol. Occup. Physiol. 50, 309-318. doi: 10.1007/ BF00423237

Maughan, R. J., Watson, J. S., and Weir, J. (1983b). Strength and cross-sectional area of human skeletal muscle. J. Physiol. 338, 37-49. doi: 10.1113/jphysiol.1983. sp014658

Nabuurs, C., Huijbregts, B., Wieringa, B., Hilbers, C. W., and Heerschap, A. (2010). 31P saturation transfer spectroscopy predicts differential intracellular macromolecular association of ATP and ADP in skeletal muscle. J. Biol. Chem. 285, 39588-39596. doi: 10.1074/jbc.M110.164665

Nabuurs, C. I., Choe, C. U., Veltien, A., Kan, H. E., Van Loon, L. J., Rodenburg, R. J., et al. (2013). Disturbed energy metabolism and muscular dystrophy caused by pure creatine deficiency are reversible by creatine intake. J. Physiol. 591, 571-592. doi: 10.1113/jphysiol.2012.241760

Nouioua, S., Cheillan, D., Zaouidi, S., Salomons, G. S., Amedjout, N., Kessaci, F., et al. (2013). Creatine deficiency syndrome. A treatable myopathy due to arginine-glycine amidinotransferase (AGAT) deficiency. Neuromuscul. Disord. 23, 670-674. doi: 10.1016/j.nmd.2013.04.011

Pettitt, S. J., Liang, Q., Rairdan, X. Y., Moran, J. L., Prosser, H. M., Beier, D. R., et al. (2009). Agouti C57BL/6N embryonic stem cells for mouse genetic resources. Nat. Methods 6, 493-495. doi: 10.1038/nmeth.1342

Puusepp, H., Kall, K., Salomons, G. S., Talvik, I., Mannamaa, M., Rein, R., et al. (2010). The screening of SLC6A8 deficiency among Estonian families with X-linked mental retardation. J. Inherit. Metab. Dis. 33(Suppl. 3), S5-S11. doi: 10.1007/s10545-008-1063-y

Pyne-Geithman, G. J., Degrauw, T. J., Cecil, K. M., Chuck, G., Lyons, M. A., Ishida, Y., et al. (2004). Presence of normal creatine in the muscle of a patient with a mutation in the creatine transporter: a case study. Mol. Cell Biochem. 262, 35-39. doi: 10.1023/B:MCBI.0000038213.15646.4a

Russell, A. P., Ghobrial, L., Wright, C. R., Lamon, S., Brown, E. L., Kon, M., et al. (2014). Creatine transporter (SLC6A8) knockout mice display an increased capacity for in vitro creatine biosynthesis in skeletal muscle. Front. Physiol. 5:314. doi: 10.3389/fphys.2014.00314

Schmidt, A., Marescau, B., Boehm, E. A., Renema, W. K., Peco, R., Das, A., et al. (2004). Severely altered guanidino compound levels, disturbed body weight homeostasis and impaired fertility in a mouse model of guanidinoacetate N-methyltransferase (GAMT) deficiency. Hum. Mol. Genet. 13, 905-921. doi: $10.1093 / \mathrm{hmg} / \mathrm{ddh} 112$

Schulze, A., Bachert, P., Schlemmer, H., Harting, I., Polster, T., Salomons, G. S., et al. (2003). Lack of creatine in muscle and brain in an adult with GAMT deficiency. Ann. Neurol. 53, 248-251. doi: 10.1002/ana.10455

Shpilka, T., and Haynes, C. M. (2018). The mitochondrial UPR: mechanisms, physiological functions and implications in ageing. Nat. Rev. Mol. Cell Biol. 19, 109-120. doi: 10.1038/nrm.2017.110

Skarnes, W. C., Rosen, B., West, A. P., Koutsourakis, M., Bushell, W., Iyer, V., et al. (2011). A conditional knockout resource for the genomewide study of mouse gene function. Nature 474, 337-342. doi: 10.1038/nature 10163

Skelton, M. R., Schaefer, T. L., Graham, D. L., Degrauw, T. J., Clark, J. F., Williams, M. T., et al. (2011). Creatine transporter (CrT; Slc6a8) knockout mice as a model of human CrT deficiency. PLoS One 6:e16187. doi: 10.1371/journal.pone. 0016187

Steeghs, K., Benders, A., Oerlemans, F., De Haan, A., Heerschap, A., Ruitenbeek, W., et al. (1997). Altered Ca2+ responses in muscles with combined mitochondrial and cytosolic creatine kinase deficiencies. Cell 89, 93-103. doi: 10.1016/S0092-8674(00)80186-5

Steeghs, K., Oerlemans, F., De Haan, A., Heerschap, A., Verdoodt, L., De Bie, M., et al. (1998). Cytoarchitectural and metabolic adaptations in muscles with mitochondrial and cytosolic creatine kinase deficiencies. Mol. Cell Biochem. 184, 183-194. doi: 10.1023/A:1006811717709

Stockebrand, M., Nejad, A. S., Neu, A., Kharbanda, K. K., Sauter, K., Schillemeit, S., et al. (2016). Transcriptomic and metabolic analyses reveal salvage pathways in creatine-deficient AGAT(-/-) mice. Amino Acids 48, 2025-2039. doi: 10.1007/ s00726-016-2202-7

Stockler, S., Isbrandt, D., Hanefeld, F., Schmidt, B., and Von Figura, K. (1996). Guanidinoacetate methyltransferase deficiency: the first inborn error of creatine metabolism in man. Am. J. Hum. Genet. 58, 914-922.

Stockler, S., Schutz, P. W., and Salomons, G. S. (2007). Cerebral creatine deficiency syndromes: clinical aspects, treatment and pathophysiology. Subcell Biochem. 46, 149-166. doi: 10.1007/978-1-4020-6486-9_8

Teerlink, T., Hennekes, M., Bussemaker, J., and Groeneveld, J. (1993). Simultaneous determination of creatine compounds and adenine nucleotides in myocardial tissue by high-performance liquid chromatography. Anal. Biochem. 214, 278-283. doi: 10.1006/abio.1993.1488

Torremans, A., Marescau, B., Possemiers, I., Van Dam, D., D'hooge, R., Isbrandt, D., et al. (2005). Biochemical and behavioural phenotyping of a mouse 
model for GAMT deficiency. J. Neurol. Sci. 231, 49-55. doi: 10.1016/j.jns.2004. 12.014

Tyler, D. J., Lopez, O., Cole, M. A., Carr, C. A., Stuckey, D. J., Lakatta, E., et al. (2010). Ongoing dual-angle measurements for the correction of partial saturation in 31P MR spectroscopy. Magn. Reson. Med. 64, 957-966. doi: $10.1002 / \mathrm{mrm} .22511$

van de Kamp, J. M., Betsalel, O. T., Mercimek-Mahmutoglu, S., Abulhoul, L., Grunewald, S., Anselm, I., et al. (2013). Phenotype and genotype in 101 males with X-linked creatine transporter deficiency. J. Med. Genet. 50, 463-472. doi: 10.1136/jmedgenet-2013-101658

van de Kamp, J. M., Errami, A., Howidi, M., Anselm, I., Winter, S., Phalin-Roque, J., et al. (2015). Genotype-phenotype correlation of contiguous gene deletions of SLC6A8, BCAP31 and ABCD1. Clin. Genet. 87, 141-147. doi: 10.1111/cge. 12355

van de Kamp, J. M., Mancini, G. M., and Salomons, G. S. (2014). X-linked creatine transporter deficiency: clinical aspects and pathophysiology. J. Inherit. Metab. Dis. 37, 715-733. doi: 10.1007/s10545-014-9713-8

van Deursen, J., Heerschap, A., Oerlemans, F., Ruitenbeek, W., Jap, P., Ter Laak, H., et al. (1993). Skeletal muscles of mice deficient in muscle creatine kinase lack burst activity. Cell 74, 621-631. doi: 10.1016/0092-8674(93)90510-W
Van Pilsum, J. F., and Warhol, R. M. (1963). The fate of large doses of creatine injected intraperitoneally into normal rats. Clin. Chem. 9, 347-350.

Wyss, M., and Kaddurah-Daouk, R. (2000). Creatine and creatinine metabolism. Physiol. Rev. 80, 1107-1213. doi: 10.1152/physrev.2000.80.3.1107

Zervou, S., Yin, X., Nabeebaccus, A. A., O’brien, B. A., Cross, R. L., Mcandrew, D. J., et al. (2016). Proteomic and metabolomic changes driven by elevating myocardial creatine suggest novel metabolic feedback mechanisms. Amino Acids 48, 1969-1981. doi: 10.1007/s00726-016-2236-x

Conflict of Interest Statement: The authors declare that the research was conducted in the absence of any commercial or financial relationships that could be construed as a potential conflict of interest.

Copyright (c) 2018 Stockebrand, Sasani, Das, Hornig, Hermans-Borgmeyer, Lake, Isbrandt, Lygate, Heerschap, Neu and Choe. This is an open-access article distributed under the terms of the Creative Commons Attribution License (CC BY). The use, distribution or reproduction in other forums is permitted, provided the original author(s) and the copyright owner are credited and that the original publication in this journal is cited, in accordance with accepted academic practice. No use, distribution or reproduction is permitted which does not comply with these terms. 